\title{
Sorption behavior of nine chromium (III) organic complexes in soil
}

\author{
1,2*Z. Luo; ${ }^{1}$ A. Wadhawan; ${ }^{1}$ E. J. Bouwer \\ ${ }^{1}$ Department of Geography and Environmental Engineering, G.W.C Whiting School of Engineering, The Johns \\ Hopkins University, Baltimore, Maryland 21218, USA \\ ${ }^{2}$ Key Laboratory of Biogeology and Environmental Geology of Ministry of Education (China University of \\ Geosciences), 388 Lumo Road, Wuhan, Hubei 430074 , China

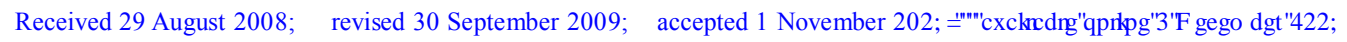

\begin{abstract}
Sorption data were obtained with a Matawan soil and the following chromium (III) organic complexes: chromium (III) ascorbate, chromium (III) glutamate, chromium (III) histidine, chromium (III) mandelate, chromium (III) citrate, chromium (III) cysteine, chromium (III) serine, chromium (III) pyruvate and chromium (III) oxalate. The influence of $\mathrm{pH}(2-12)$, ionic strength $(0.005-1 \mathrm{M})$ and concentration of sorbate $(1-10 \mathrm{mg} / \mathrm{L})$ on the extent of sorption was evaluated. The $\mathrm{pH}$ value did not influence the percent sorption at environmentally relevant $\mathrm{pH} 7$. Ionic strength between 0.005 and $0.01 \mathrm{M} \mathrm{KNO}_{3}$ did not influence the sorption. Sorption and desorption data obtained at $\mathrm{pH}$ 7, $0.01 \mathrm{M} \mathrm{KNO}_{3}$ and 1-10 mg/L for each chromium (III) organic complex were analyzed using Freundlich and Langmuir models. The Freundlich model provided good fits for all of the chromium (III) organic complexes. Sorption data for chromium (III) glutamate, chromium (III) pyruvate, chromium (III) oxalate, chromium (III) cysteine, chromium (III) ascorbate and chromium (III) citrate were described well by the Langmuir model. Estimates for the saturated sorption capacities were 141, 70.9, 36.5, 35.5, 28.6 and $4.4 \mu \mathrm{g} / \mathrm{g}$, respectively. It was not possible to desorb significant amounts of the previously sorbed chromium (III) organic complexes. At the same $\mathrm{pH}$, ionic strength and solid:liquid ratio, the order of the observed sorption to the Matawan soil from highest to lowest was chromium (III) mandelate, chromium (III) glutamate, chromium (III) histidine, chromium (III) cysteine, chromium (III) serine, chromium (III) pyruvate, chromium (III) oxalate, chromium (III) ascorbate and chromium (III) citrate.
\end{abstract}

Keywords: Chromium (III) ascorbate; Chromium (III) histidine; Chromium (III) citrate; Chromium (III) cysteine; Chromium (III) serine; Desorption; Freundlich isotherm

\section{INTRODUCTION}

Chromium (Cr) exists in the natural environment primarily as the mineral chromite, $\mathrm{FeOCr}_{2} \mathrm{O}_{3}$ (Vitale $e t$ al., 1997). Mining activities and natural weathering cause $\mathrm{Cr}$ to be distributed as: 1 ) solid $\mathrm{Cr}$ (III) species: $\mathrm{Cr}(\mathrm{OH})_{3}(\mathrm{~s}),(\mathrm{Fe}, \mathrm{Cr})(\mathrm{OH})_{3}(\mathrm{~s})$ and $\left.\mathrm{Cr}_{2} \mathrm{O}_{3}, 2\right)$ dissolved $\mathrm{Cr}$ (III) species: $\mathrm{CrOH}^{2+}, \mathrm{Cr}(\mathrm{OH})_{2}{ }^{+}$and $\left.\mathrm{Cr}(\mathrm{OH})_{3}, 3\right)$ dissolved $\mathrm{Cr}(\mathrm{VI})$ species: $\mathrm{HCrO}_{4}, \mathrm{CrO}_{4}^{2 "}$ and $\mathrm{Cr}_{2} \mathrm{O}_{7}{ }^{2-}$ (Sass and Rai, 1987; Richard and Bourg, 1991; Shah et al., 2009) and IV) elemental Cr (0). Past research has focused on behavior and removal mechanisms of $\mathrm{Cr}$ (VI) because of its relative high toxicity to aquatic organisms, (Ogundiran and Afolabi, 2008) which stems from its higher aqueous solubility and greater ability in comparison to $\mathrm{Cr}$ (III) to penetrate across the cell membrane (Oshida et al., 1981; Holdway, 1988; Nieboer and Jusys, 1988; Wang et al., 1997; Sivakumar

*Corresponding Author Email: zjluo@cug.edu.cn

Tel.: +861 347621 2088; Fax +862787436235 and Subbhuraam, 2005). Although Costa (2003) also suggests that $\mathrm{Cr}$ (III) not entering the cell might cause signaling pathways. This is a phenomenon which has been associated Cadmium and the induction of metallothionen (Huang et al., 2001; Adams et al., 2002). Growing evidence indicates that soluble $\mathrm{Cr}$ (III) organic complexes can form with natural organic matter in the environment (Nakayama et al., 1981; Ahern et al., 1985; Kaczynski and Kieber, 1994; Icopini and Long, 2002; Shrestha et al., 2007) and become bioavailable (Davis et al., 1994; Kaczynski and Kieber, 1994; Fukushima et al., 1995; Mattuck and Nikolaidis, 1996; Walsh and O'Halloran, 1996; 1997; Howe et al., 2003). For example, it was estimated that $60 \%$ of the total dissolved chromium in the Sea of Japan exists as Cr organic complexes (Nakayama et al., 1981) and the fraction of the total dissolved chromium in Australian coastal waters as $\mathrm{Cr}$ organic complexes ranged from 0 
to $90 \%$ (Ahern et al., 1985). Cr organic complexes, like other metal-organic complexes, are mobile in soil and recalcitrant to short term biodegradation processes. $\mathrm{Cr}$ (III) citrate showed little sorption to soil; $\mathrm{Cr}$ (III) malate had limited partitioning with soil; and $\mathrm{Cr}$ (III) histidine exhibited significant interaction with soil (Puzon et al., 2008). The mobility appeared to vary depending on the organic ligand. Further, Ralstonia eutropha JMP 134 and Pseudomonas aeruginosa pAO1 readily degraded malate, citrate and histidine, but not the corresponding $\mathrm{Cr}$ (III) organic complexes (Puzon et al., 2008). Icopipi and Long (2002) indicate that the elevated aqueous chromium concentrations in surface and pore water were induced from complexation with organic ligands. Considering the redox behavior of chromium and interaction with organic ligands in nature, the geochemical cycle of chromium is shown in Fig. 1. There is strong evidence that $\mathrm{Cr}$ (III) organic complexes exist in nature. $\mathrm{Such} \mathrm{Cr}$ (III) organic complexes might be decomposed and became inorganic $\mathrm{Cr}$ (III), might be reoxidized to $\mathrm{Cr}$ (VI) and became toxic and might be sorbed by solid particles and became sequestered. Cr (III) organic complexes likely play an important role in the distribution and behavior of chromium in the natural environment, which in turn could influence $\mathrm{Cr}$ speciation and toxicity to organisms.

$\mathrm{Cr}$ (III) forms strong complexes with amine and carboxylate Lewis Base groups (Pearson, 1963), which are common constituents of natural organic matter in the environment. Complexation with these multidentate aminocarboxylate ligands has been shown to cause dissolution of amorphous $\mathrm{Cr}(\mathrm{OH})_{3}(\mathrm{~s})$, thereby increasing the mobility and bioavailability of $\mathrm{Cr}$ (III) in aquatic environments (Carbonaro and Stone, 2005; Shrestha et al., 2007). The fate of these mobile and bioavailable $\mathrm{Cr}$ (III) organic complexes in the environment is not well understood. Questions remain as to whether chromium mobility is increased when present as soluble $\mathrm{Cr}$ (III) organic complexes or decreased by being combined as macromolecular complexes. This work focused on determining the extent of sorption of $\mathrm{Cr}$ (III) organic complexes to solid particles.

Sorption of $\mathrm{Cr}$ (III) organic complexes onto Current literature suggests that natural organic ligands influence the transport of heavy metals in soils and infiltration into groundwater systems (von Gunten and Kull, 1986; Stumm and Morgan, 1996; Buerge-
Weirich et al., 2003) due to their complexation and sorption properties. For the soluble Cr (III) organic complexes, can they be sorbed by soil or sediment particles? How easily can they be desorbed? In this work, the influence of varying $\mathrm{pH}$ and ionic strength on sorption of model $\mathrm{Cr}$ (III) organic complexes to a Matawan soil is examined. The organic ligands used to form $\mathrm{Cr}$ (III) organic complexes include glutamic acid (glu), histidine (his), cysteine (cys), serine (ser), mandelic acid (mand), ascorbic acid (asc), citrate (cit), pyruvic acid (pyr) and oxalate (oxa). These ligands were chosen because they are common in the natural environment and can form complexes with $\mathrm{Cr}$ (III).

This research was carried in the lab of the Department of Geography and Environmental Engineering, G.W.C Whiting School of Engineering, the Johns Hopkins University, Baltimore, Maryland, USA from May, 2005 to September, 2006.

\section{MATERIALS AND METHODS}

\section{Chemical reagents}

All chemicals were reagent grade or better and were used without further purification. Ascorbic acid, glutamic acid, cysteine and serine were purchased from Sigma (St. Louis, MO). Sodium hydroxide $(\mathrm{NaOH})$, chromium chloride $\left(\mathrm{CrCl}_{3} \cdot 6 \mathrm{H}_{2} \mathrm{O}\right)$, disodium hydrogen phosphate $\left(\mathrm{Na}_{2} \mathrm{HPO}_{4}\right)$, sodium dihydrogen phosphate $\left(\mathrm{NaH}_{2} \mathrm{PO}_{4}\right)$, potassium hydrogen phthalate $\left(\mathrm{KHC}_{8} \mathrm{H}_{4} \mathrm{O}_{4}\right)$, sodium borate decahydrate $\left(\mathrm{Na}_{2} \mathrm{~B}_{4} \mathrm{O}_{7} \cdot 10 \mathrm{H}_{2} \mathrm{O}\right)$ and sodium bicarbonate $\left(\mathrm{NaHCO}_{3}\right)$ were purchased from J. T. Baker (Phillipsburg, NJ). Lhistidine, sodium citrate, sodium oxalate, potassium nitrate $\left(\mathrm{KNO}_{3}\right)$ and sodium azide $\left(\mathrm{NaN}_{3}\right)$ were purchased from Fisher (Fair Lawn, NJ). Mandelic acid, pyruvate acid sodium, and nitric acid $\left(\mathrm{HNO}_{3}\right)$ were purchased from Acros (Fair Lawn, NJ), Kodak (Rochester, NY) and Fluka (France), respectively. All solutions were prepared with Milli-Q (18 M $2-\mathrm{cm})$ water (Millipore Corp., Milford, MA). The Cr (III) stock solution $(1,000 \mathrm{mg} / \mathrm{L}, 19.23 \mathrm{mM})$ was prepared by dissolving $\mathrm{CrCl}_{3} \cdot 6 \mathrm{H}_{2} \mathrm{O}$ in a $0.01 \mathrm{M} \mathrm{HNO}_{3}$ (Fisher Scientific) solution.

\section{Soil}

The soil used in this study was a Matawan soil obtained from the USDA Agricultural Research Center in Beltsville, Maryland. The characteristics of this test soil are summarized in Table 1. The information was obtained in part from the USDA and in part from 
measurements in the same laboratory mentioned hereabove.

\section{Methods}

$\mathrm{Cr}$ (III) organic complexes were prepared by mixing $250 \mathrm{mLs}$ of a $20 \mathrm{mM}$ solution of each organic ligand with $250 \mathrm{mLs}$ of a $5 \mathrm{mM} \mathrm{Cr}$ (III) solution. The $5 \mathrm{mM} \mathrm{Cr}$ (III) solution was prepared by diluting the stock $\mathrm{Cr}$ (III) solution at $\mathrm{pH} 3-4$. The combined solutions were mixed on a rotator for 12 days at $30 \pm 2{ }^{\circ} \mathrm{C}$. At the end of the mixing period, the uncomplexed $\mathrm{Cr}$ (III) was precipitated out from the solution as $\mathrm{Cr}(\mathrm{OH})_{3}(\mathrm{~s})$ by raising the $\mathrm{pH}$ to 8.1 with $10 \mathrm{M} \mathrm{NaOH}$ and filtering the solution using a $0.20 \mu \mathrm{m}$ filter (SFCA/PF, Corning, Germany). A pH meter (Fisher Accumet Model 15) with Ross combination Electrode (Fisher, Accumet) was used to monitor the solution $\mathrm{pH}$.

The stability of $\mathrm{Cr}$ (III) organic complexes (working solution was $10 \mathrm{~mL}$ and about $190 \mu \mathrm{M}$ (Cr (III) organic) as a function of $\mathrm{pH}$ was assessed in batch tests before the soil sorption experiment. All buffer stock solutions were prepared first at $50 \mathrm{mM}$. Then reaction solutions were added: $2.5 \mathrm{mLs}$ of the $0.8 \mathrm{mM} \mathrm{Cr}$ (III) organic bulk complex solution and $1 \mathrm{~mL}$ of the $50 \mathrm{mM} \mathrm{pH}$ buffer solution, diluted to $10 \mathrm{mLs}$ with MW. The $\mathrm{pH}$ was measured. The mixtures were reacted for $48 \mathrm{~h}$. A $\mathrm{KHC}_{8} \mathrm{H}_{4} \mathrm{O}_{4}$ buffer was used for $\mathrm{pH} 4$ and $\mathrm{pH} 5$, a $\mathrm{NaH}_{2} \mathrm{PO}_{4}$ and $\mathrm{Na}_{2} \mathrm{HPO}_{4}$ buffer for $\mathrm{pH} 6.8$, a NaH $\mathrm{PO}_{4}$ buffer for $\mathrm{pH} 7.4$, a Na $\mathrm{B}_{4} \mathrm{O}_{7} \cdot 10 \mathrm{H}_{2} \mathrm{O}$ buffer for $\mathrm{pH} 9.1$ and $\mathrm{NaHCO}_{3}$ buffer for $\mathrm{pH} 10.0$ (Clesceri et al., 1989). For batches with pHs below 4.0 and above 11.0, no buffers were used; the $\mathrm{pH}$ was adjusted by adding $\mathrm{HNO}_{3}$ and $\mathrm{NaOH}$, respectively. The phosphate was chosen as a $\mathrm{pH}$ buffer according to the literature (Puzon et al., 2005). $48 \mathrm{~h}$ later, the samples were filtered $(0.2 \mu \mathrm{m}, \mathrm{SFCA} / \mathrm{PF}$, Corning, Germany) and tested by atomic absorption spectrometry (AAS).
The sorption of $\mathrm{Cr}$ (III) organic complexes to the Matawan soil was evaluated in a series of batch experiments. One gram of soil was placed in a series of $15 \mathrm{~mL}$ disposable polypropylene centrifuge tubes (Falcon, NJ), with $3 \mathrm{mM}$ of $\mathrm{NaN}_{3}$ to inhibit bacterial growth. An appropriate volume of each $\mathrm{Cr}$ (III) organic solution was added to each tube. The influence of $\mathrm{pH}$ on sorption of the $\mathrm{Cr}$ (III) organic complexes was examined by setting up tubes to span a range of $\mathrm{pHs}$. Each tube consisted of $5 \mathrm{mM} \mathrm{pH}$ buffer, $10 \mathrm{mg} / \mathrm{L}$ Cr (III) organic complex and 1:10 soil solid:liquid ratio. The same $\mathrm{pH}$ buffers described above were used.

The effect of ionic strength on $\mathrm{Cr}$ (III) organic sorption was examined by setting up a series of tubes containing $10 \mathrm{mg} / \mathrm{L}$ of the $\mathrm{Cr}$ (III) organic and $1 \mathrm{M}, 0.1$ $\mathrm{M}, 0.05 \mathrm{M}, 0.01 \mathrm{M}$ and $0.005 \mathrm{M} \mathrm{KNO}_{3}$. The $\mathrm{pH}$ of all these batches was adjusted to 7.0 using $5 \mathrm{mM}$ $\mathrm{NaH}_{2} \mathrm{PO}_{4}$ and $\mathrm{Na}_{2} \mathrm{HPO}_{4}$ buffer. $3 \mathrm{mM} \mathrm{NaN}_{3}$ was also added.

Another set of tubes was prepared to examine the influence of $\mathrm{Cr}$ (III) organic concentration on sorption behavior. Tubes were prepared containing 1, 2, 3, 4, $5,6,7,8,9$ and $10 \mathrm{mg} / \mathrm{L}$ of each Cr (III) organic, $5 \mathrm{mM}$ of a $\mathrm{NaH}_{2} \mathrm{PO}_{4}$ and $\mathrm{Na}_{2} \mathrm{HPO}_{4}$ buffer (pH 7), $10 \mathrm{mM} \mathrm{KNO}_{3}$ and $3 \mathrm{mM} \mathrm{NaN}_{3}$. Each tube was mixed at $30 \pm 2{ }^{\circ} \mathrm{C}$ on a rotator (4609C ROTATOR, Glass-Col Model 099ARD-4512 Rotator) for 10 day. After culmination of the sorption mixing period, each tube was centrifuged at $4000 \mathrm{~g}$ for $40 \mathrm{~min}$ and the supernatant was filtered $(0.2$ $\mu \mathrm{m}$, SFCA/PF, Corning, Germany) and tested by AAS. The amount of $\mathrm{Cr}$ (III) organic that could be subsequently desorbed from soil was determined by adding $10 \mathrm{~mL}$ DI water with $5 \mathrm{mM} \mathrm{pH}$ buffer, $10 \mathrm{mM}$ $\mathrm{KNO}_{3}$ and $3 \mathrm{mM} \mathrm{NaN}_{3}$, to the soil remaining in the batch tubes after centrifugation. The mixture in each tube was mixed for 10 day and centrifuged at $4000 \mathrm{~g}$ for $40 \mathrm{~min}$. The supernatant was filtered $(0.2 \mu \mathrm{m}$,

Table 1: Characteristics of the Matawan Soil (dwt., average \pm standard deviation)

\begin{tabular}{|c|c|c|c|c|c|}
\hline Characteristics* & Concentration & Methods** & Metals & 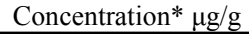 & Methods \\
\hline Clay & $2-10 \%$ & USDA sampling & $\mathrm{Cr}$ & $6.3 \pm 0.1$ & EPA method 3051 ICP-MS with \\
\hline $\mathrm{OC}$ & $2 \%$ & USDA sampling & $\mathrm{Zn}$ & $63.4 \pm 2.1$ & \\
\hline DOC & $0.53 \pm 0.04$ & UV-persulfate TOC & $\mathrm{Cd}$ & $0.25 \pm 0.01$ & \\
\hline \multirow[b]{2}{*}{ Surface area } & $\mathrm{mg} \mathrm{C} / \mathrm{g}$ soil & Analyzer (Dohrmann) & & & \\
\hline & $\begin{array}{l}3.62 \pm 0.13 \\
\mathrm{~m}^{2} / \mathrm{g} \text { soil }\end{array}$ & B.E.T. $\mathrm{N}_{2}$ adsorption & $\mathrm{Ni}$ & $3.4 \pm 0.08$ & \\
\hline
\end{tabular}

*OC $=$ organic carbon; $\mathrm{DOC}=$ dissolved organic carbon

**Data provided from the USDA Agricultural Research Center in Beltsville, MD. 
SFCA/PF, Corning, Germany) and tested for chromium by AAS.

The percent sorption and the distribution coefficient were calculated by computing a mass balance for each batch test. The amount sorbed was determined from the difference between the initial and the equilibrium concentrations of the sorbate. To reduce error in the sorption calculations, all batches were designed so that the equilibrium solution concentrations fell between $15 \%$ and $85 \%$ of the initial $\mathrm{Cr}$ (III) organic concentration. If not otherwise stated the all the experiment were performed in triplicate and calculated the average.

\section{RESULTS AND DISCUSSION}

Effect of pH on Cr (III) organic complexes and its sorption

The influence of $\mathrm{pH}$ on the stability of $\mathrm{Cr}$ (III) organic complexes is shown in Fig. 2. Most $\mathrm{Cr}$ (III) organic were independent of $\mathrm{pH}$ except for $\mathrm{Cr}$ (III) cys. $\mathrm{Cr}$ (III) cys complex was not stable as $\mathrm{pH}$ value below 7.0 and became precipitated at $\mathrm{pH}$ value below 3.9. After filtering, the soluble $\mathrm{Cr}$ (III) concentration was decreased from $9.88 \mathrm{mg} / \mathrm{L}(\mathrm{pH}>7.0)$ to $1.35 \mathrm{mg} /$ $\mathrm{L}(\mathrm{pH}<3.9)$. $\mathrm{Cr}(\mathrm{III})$ mand complex show a wave from $\mathrm{pH} 5.0$ to 7.0 due to the measurement error.

The effect of $\mathrm{pH}$ on percent sorption of each $\mathrm{Cr}$ (III) organic complex to the Matawan soil is shown in Fig. 3. For all of the $\mathrm{Cr}$ (III) organic complexes except $\mathrm{Cr}$ (III) glu, Cr (III) cys, Cr (III) mand and Cr cit, the percent sorption to the Matawan soil was independent of the $\mathrm{pH}$ over the $\mathrm{pH}$ range 2 to 12 . The $\mathrm{Cr}$ (III) mand complex showed greater sorption at $\mathrm{pH}$ less than 5 than at $\mathrm{pH} 7$ and above 7 . Cr (III) glut, $\mathrm{Cr}$ (III) his, $\mathrm{Cr}$ (III) mand and $\mathrm{Cr}$ (III) ser complexes were sorbed less at $\mathrm{pH} 12$ than at $\mathrm{pH}$ below 12. The sorption of $\mathrm{Cr}$ (III) asc and $\mathrm{Cr}$ (III) pyr complexes tended to remain constant over the entire $\mathrm{pH}$ range studied. The Cr (III) oxa complex sorbed the most at pH 12. The $\mathrm{Cr}$ (III) cys and $\mathrm{Cr}$ (III) glu complex was stable at pH from 7 to 10 . Cr-III cit exhibited higher sorption at $\mathrm{pH}$ less than 3. Above $\mathrm{pH} 3$, the percent sorption decreased with increasing $\mathrm{pH}$.

In general, the $\mathrm{pH}$ dependence of soil sorption results from surface complexation, ligand exchange, the electrostatic interactions induced from surface charge, and the hydrophobic or hydrophilic interactions between the sorbate and soil at different pHs condition. The Matawan soil in this study had 2
- $10 \%$ clay content and $2 \%$ organic carbon (Table 1 ). Ge and Hendershot (2004) suggested that such a soil has a low anion exchange capacity and carries mostly a negative surface charge. The surface reactions for such a soil involve only neutral ( $\equiv \mathrm{SiOH})$ or negatively $\left(\mathrm{SiO}^{-}\right)$charged surface functional groups. The ionexchange reaction of soil and anionic complexes, such as $\mathrm{Cr}$ (III) glutamate with $\mathrm{OH}^{-}$of $\mathrm{XOH}$, may occur through the following equilibrium reaction:

$$
\mathrm{XOH}+\left[\mathrm{Cr}^{3} \mathrm{~L}_{2}\right]^{-}=\mathrm{XOCr}^{3} \mathrm{~L}_{2}+\mathrm{OH}^{-}
$$

According to Eq. 1, increasing the $\mathrm{pH}$ may reduce the ion-exchange competition of the anion $\mathrm{Cr}$ (III) organic complex with the $\mathrm{OH}$ - of $\mathrm{XOH}$ and decrease the possibility of $\mathrm{Cr}$ (III) organic sorbing onto the soil. In addition, with decreasing $\mathrm{pH}$, the fraction of the neutral $\mathrm{Cr}$ (III) organic complex such as $\mathrm{Cr}$ (III) mand may increase, which enhances the hydrophobic effect of the complex from the bulk solution, leading to increased sorption.

In addition, $\mathrm{pH}$ could change sorbate charges and molecular structures. For example, Cr (III) cit complex might decompose at $\mathrm{pH}$ less than 3 since it was prepared by $\mathrm{CrCl}_{3}$ and organic compounds. The dominant forms of $\mathrm{Cr}$ (III) are likely to be $\left[\mathrm{Cr}^{3}\left(\mathrm{H}_{2} \mathrm{O}\right) \mathrm{Cl}_{2}\right]^{+},\left[\mathrm{Cr}^{3}\left(\mathrm{H}_{2} \mathrm{O}\right)_{5} \mathrm{Cl}\right]^{2+}$ and $\left[\mathrm{Cr}^{3}\left(\mathrm{H}_{2} \mathrm{O}\right)_{6}\right]^{3+}$ (Gaspar and Buglyo, 2000) and be sorbed onto the soil surface. A similar reaction might be applied to the other complexes. The percent of sorption onto the soil was low and all around $17 \%$. At extremely high $\mathrm{pH}$, such as 11 to $12, \mathrm{Cr}$ (III) glu, Cr (III) ser, Cr (III) his and $\mathrm{Cr}$ (III) mand complexes showed lower percent of sorption, possibly due to zero or negative charges on the molecules.

\section{Influence of ionic strength on Cr (III) organic sorption \\ This batch experiment consisted of $5 \mathrm{mM} \mathrm{pH}$ buffer, $3 \mathrm{mM} \mathrm{NaN}_{3}$ and $10 \mathrm{mg} / \mathrm{L}$ of the $\mathrm{Cr}$ (III) organic. \\ The ionic strength for the solution conditions was nearly $0.01 \mathrm{M}$, therefore, the influence of increasing the ionic strength above $0.01 \mathrm{M}$ on $\mathrm{Cr}$ (III) organic sorption is shown in Fig. 4. Sorption of Cr (III) asc, $\mathrm{Cr}$ (III) cit andCr (III) oxa remained fairly unchanged whereas that of $\mathrm{Cr}$ (III) glu, $\mathrm{Cr}$ (III) mand and $\mathrm{Cr}$ (III) pyr increased with increasing ionic strength. This increase in the sorption was likely due to changes in the soil surface charge at higher ionic strengths. The sorption of $\mathrm{Cr}$ (III) his decreased with increasing ionic strength}


in the range of $0.01-1.0 \mathrm{M} \mathrm{KNO}_{3}$. The $\mathrm{Cr}$ (III) his complex is cationic, so increasing ionic strength leads to an increase in soil cation exchange capacity. Cr (III) cys and $\mathrm{Cr}$ (III) ser complexes precipitated at ionic strengths greater than $0.01 \mathrm{M} \mathrm{KNO}_{3}$ and $\mathrm{Cr}$ (III) mand precipitated at an ionic strength of $1.0 \mathrm{M} \mathrm{KNO}_{3}$. However, sorption data are not available for the precipitated complexes. Based on these data, sorption with an ionic strength of $0.01 \mathrm{M} \mathrm{KNO}_{3}$ provided the best overall results for the subsequent experiments.

\section{Sorption isotherms}

The experimental data obtained in this study were analyzed by the following three sorption isotherm models, Linear isotherm, Langmuir isotherm (Langmuir, 1918) and Freundlich isotherm (Freundlich, 1926).

The sorption data for the Langmuir and Freundlich

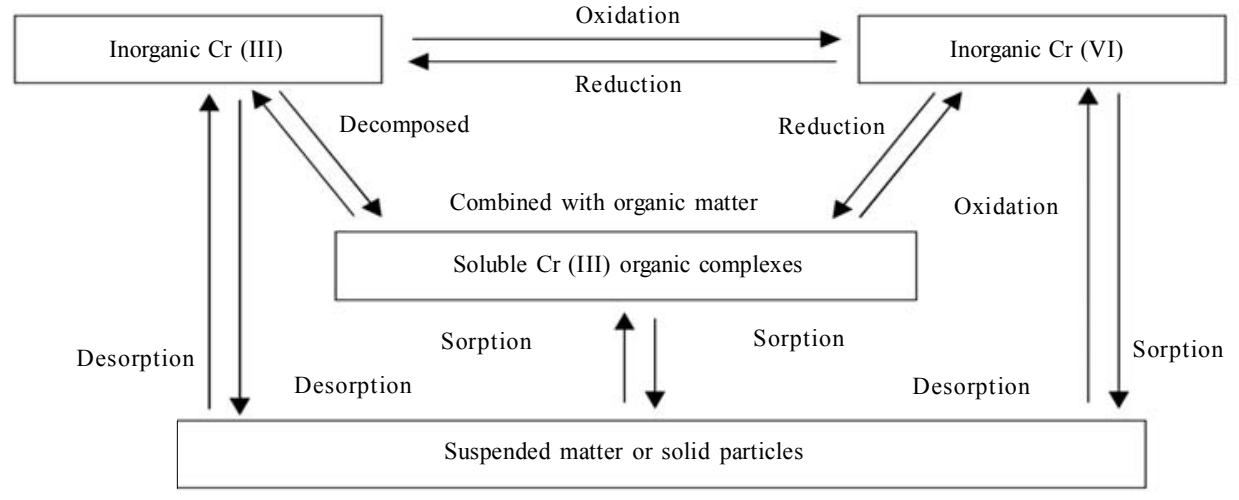

Fig. 1: The geochemical cycle of $\mathrm{Cr}$ in nature (Puzon et al., 2005)
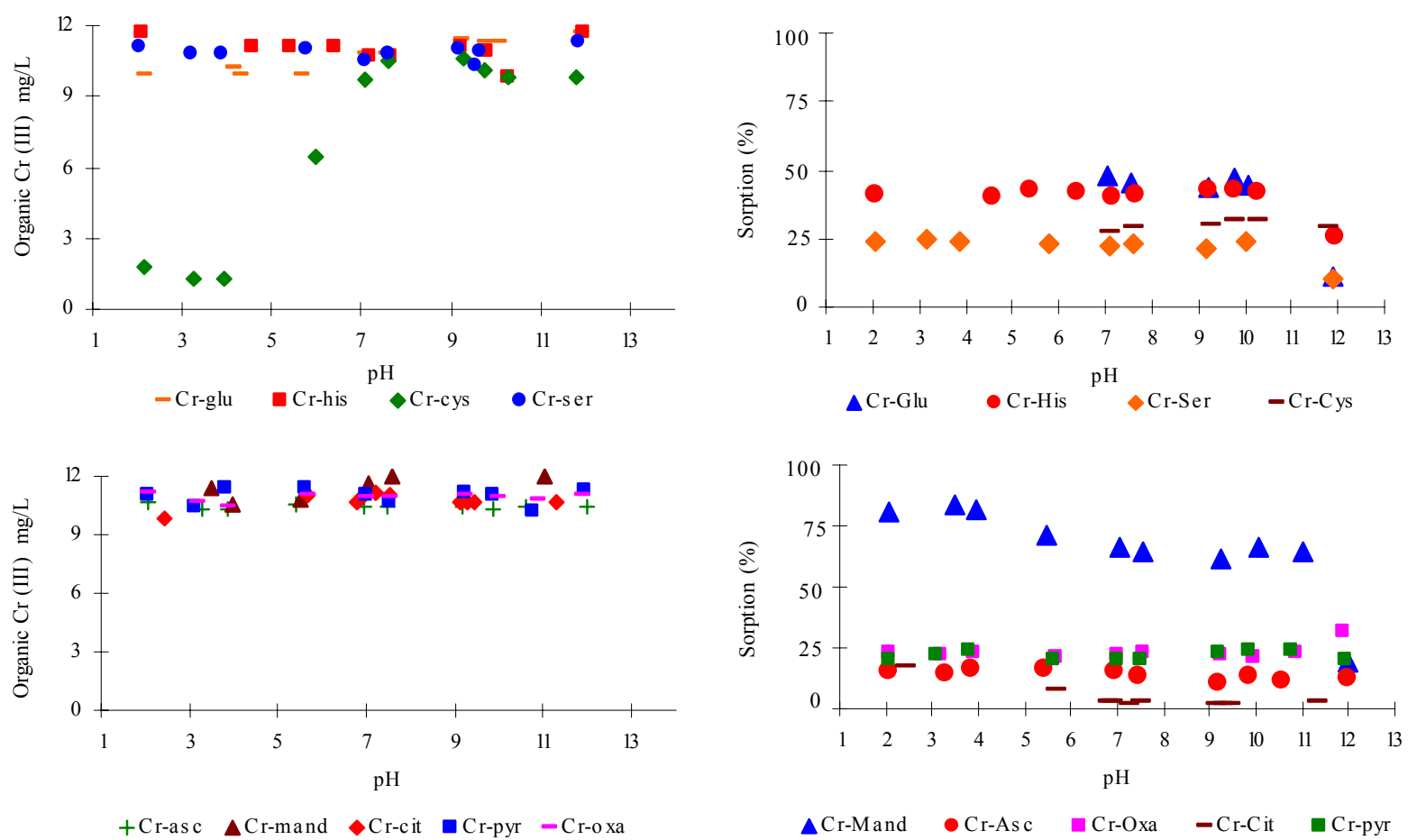

Fig. 2: Stability of organic Cr (III) complexes as a function of $\mathrm{pH}$ at $30 \pm 2{ }^{\circ} \mathrm{C}$ and contact time of $48 \mathrm{~h}$

Fig. 3: Percent of each Cr (III) organic complex sorbed onto the Matawan soil as a function of $\mathrm{pH}$ at $30 \pm 2{ }^{\circ} \mathrm{C}$ and contact time of 10 days 

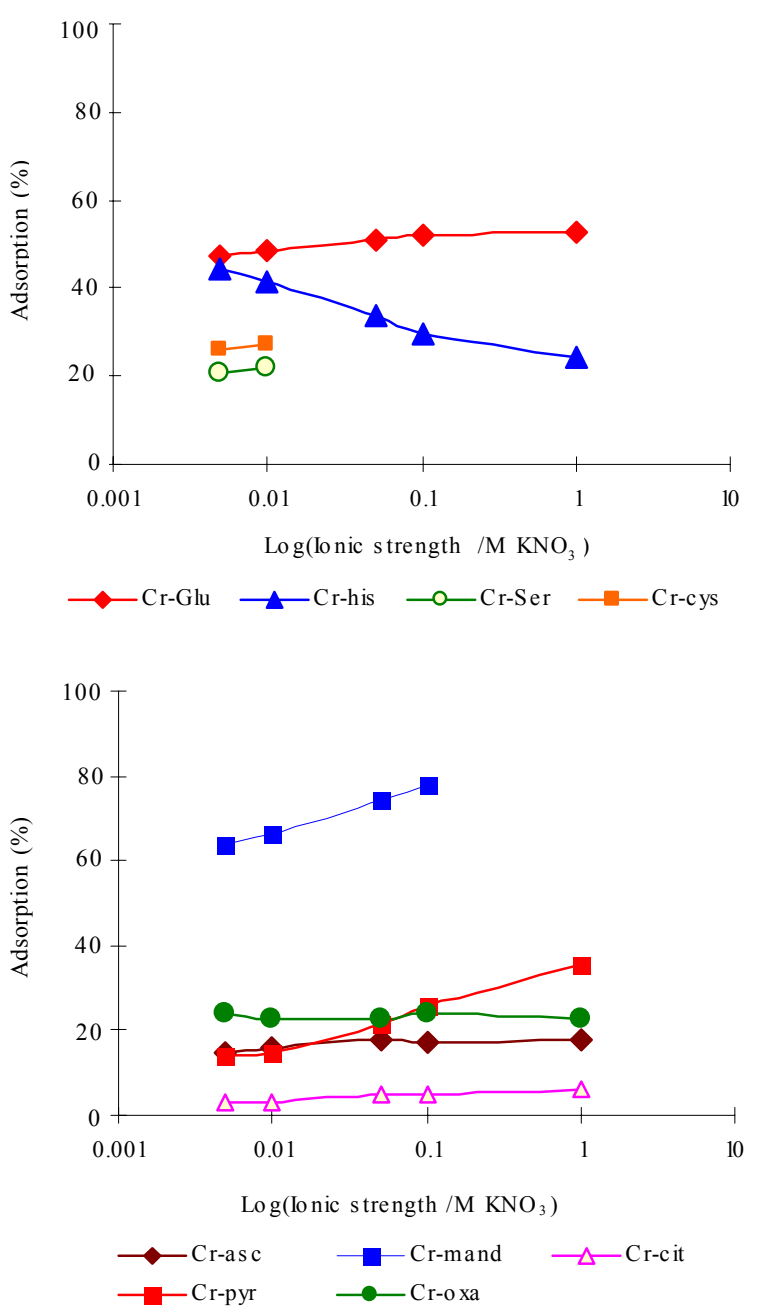

Fig. 4: Percent of each $\mathrm{Cr}$ (III) organic complex sorbed onto the Matawan soil as a function of ionic strength at 30 $\pm 2{ }^{\circ} \mathrm{C}$ and contact time of $10 \mathrm{~d}$. The ionic strength was controlled with $\mathrm{KNO}_{3}$ isotherms are shown in Fig. 5. The best fit coefficients for the isotherms are summarized in Table 2. The sorption of Cr (III) asc, $\mathrm{Cr}$ (III) glu, $\mathrm{Cr}$ (III) cit, $\mathrm{Cr}$ (III) cys, Cr (III) pyr and Cr (III) oxa complexes were described well by both the Langmuir and the Freundlich models. The sorption data for the Cr (III) cit complex were described better by the Freundlich isotherm in comparison to the Langmuir isotherm. The good fits to the Freundlich model might be because the Langmuir isotherm has more restrictive assumptions (i.e., single layer sorption, homogeneous surface and bonding energies and no interaction among the compound and the surface) than the Freundlich isotherm in explaining adsorption phenomena (Petruzzelli et al., 1985).

Even though $\mathrm{Cr}$ (III) glu, $\mathrm{Cr}$ (III) pyr, $\mathrm{Cr}$ (III) oxa, $\mathrm{Cr}$ (III) cys, $\mathrm{Cr}$ (III) asc and $\mathrm{Cr}$ (III) cit complexes are negatively charged at neutral $\mathrm{pH}$ (data to be published in a follow-on paper), their sorption capacities with the Matawan soil differed (Table 2). The properties of the different ligands are likely contributing to the observed The observed differences in sorption behavior.

The sorption data for the $\mathrm{Cr}$ (III) his, $\mathrm{Cr}$ (III) mand and $\mathrm{Cr}$ (III) ser complexes were described only by the Freundlich model with values of $\mathrm{n}$ being 1.33 , 1.78 and 1.20 , respectively. These values of $n$ are greater than one, suggesting that cooperative sorption was involved. The cooperative sorption behavior for the $\mathrm{Cr}$ (III) his, $\mathrm{Cr}$ (III) mand and $\mathrm{Cr}$ (III) ser complexes likely stems from their existence as more than one species (the data will be published in a subsequent manuscript). For the $\mathrm{Cr}$ (III) cys complex, both the Langmuir and the Freundlich models showed poor fits with the sorption data

Table 2: Fitted sorption and desorption parameters for the Langmuir and Freundlich models at $30 \pm 2{ }^{\circ} \mathrm{C}$

\begin{tabular}{|c|c|c|c|c|c|c|c|c|c|c|}
\hline \multirow{3}{*}{$\mathrm{Cr}$ (III) organic complex } & \multicolumn{5}{|c|}{ Langmuir model } & \multicolumn{5}{|c|}{ Freundlich model } \\
\hline & \multicolumn{3}{|c|}{ sorption } & \multicolumn{2}{|c|}{ desorption } & \multicolumn{3}{|c|}{ sorption } & \multicolumn{2}{|c|}{ desorption } \\
\hline & $\mathrm{K}_{1}$ & $\mathrm{Q}_{0}(\mu \mathrm{g} / \mathrm{g})$ & $\mathrm{r}^{*}$ & $\mathrm{~K}_{1}{ }^{\prime}$ & r* & $\mathrm{n}$ & $\mathrm{K}_{2}$ & $\mathrm{r}^{*}$ & $\mathrm{~N}^{\prime}$ & $\mathrm{r}^{*}$ \\
\hline $\mathrm{Cr}$ (III) asc & 0.22 & 28.57 & 0.99 & 0.03 & 0.98 & 0.64 & 4.47 & 0.99 & 0.62 & 0.97 \\
\hline $\mathrm{Cr}$ (III) glu & 0.05 & 140.85 & 1 & & & 0.65 & 19.67 & 1 & & \\
\hline $\mathrm{Cr}$ (III) his & & & & & & 1.33 & 3.72 & 1 & 1.04 & 0.99 \\
\hline $\mathrm{Cr}$ (III) mand & & & & & & 1.78 & 45.65 & 0.98 & & \\
\hline $\mathrm{Cr}$ (III) cit & 0.41 & 4.4 & 0.93 & 0.05 & 0.96 & 0.37 & 1.75 & 0.94 & 0.47 & 0.94 \\
\hline $\mathrm{Cr}$ (III) cys & 0.10 & 35.46 & 0.86 & & & 0.40 & 10.70 & 0.77 & & \\
\hline $\mathrm{Cr}$ (III) ser & & & & & & 1.20 & 1.85 & 0.96 & & \\
\hline $\mathrm{Cr}$ (III) pyr & 0.30 & 70.92 & 0.99 & 0.02 & 0.99 & 0.89 & 3.21 & 0.99 & 0.729 & 0.99 \\
\hline Cr (III) oxa & 0.17 & 36.5 & 0.97 & 0.003 & 0.96 & 0.69 & 5.34 & 0.96 & 0.56 & 0.97 \\
\hline
\end{tabular}

*Correlation coefficients 
(correlation coefficient values of 0.862 and 0.767 , respectively). A contributing factor is the $\mathrm{Cr}$ (III) cys complex with its - $\mathrm{SH}$ group was not stable as it is subject to oxidation upon exposure to air to form a cysteine complex. Sorption of all the $\mathrm{Cr}$ (III) organic complexes with the Matawan soil were described well by the Freundlich model, with the Cr (III) asc, $\mathrm{Cr}$ (III) glu, $\mathrm{Cr}$ (III) cit, $\mathrm{Cr}$ (III) cys and $\mathrm{Cr}$ (III) oxa complexes
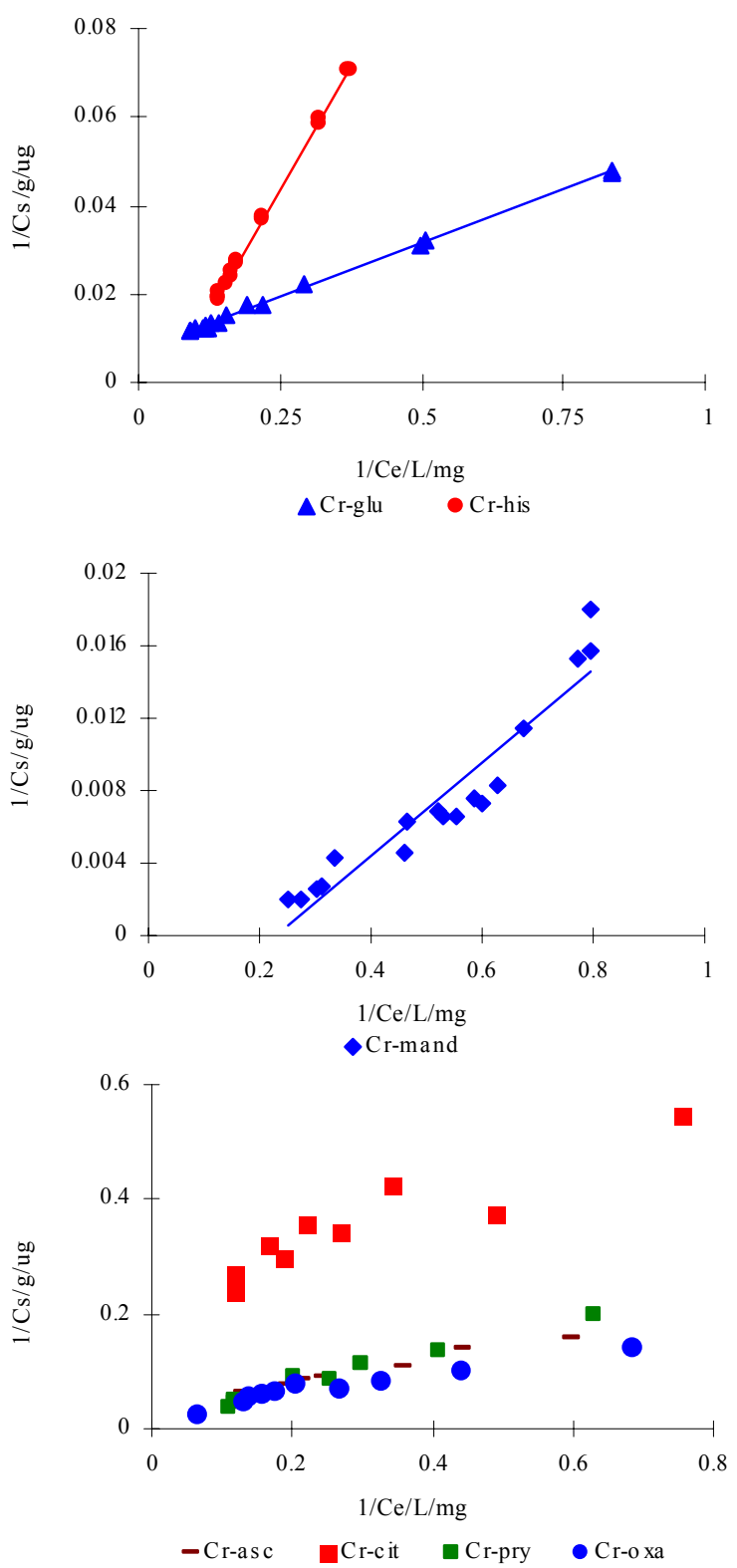

having nonlinear sorption isotherms $(\mathrm{n}=0.37-0.69)$ and the $\mathrm{Cr}$ (III) pyr complex having a nearly linear isotherm $(n=0.89)$.

The desorption data are presented in Fig. 6 and the behavior of the $\mathrm{Cr}$ organic complexes provided insight into the bioavailable fraction and mobility. Desorption of the Cr (III) organic complexes was essentially irreversible. Since limited desorption was
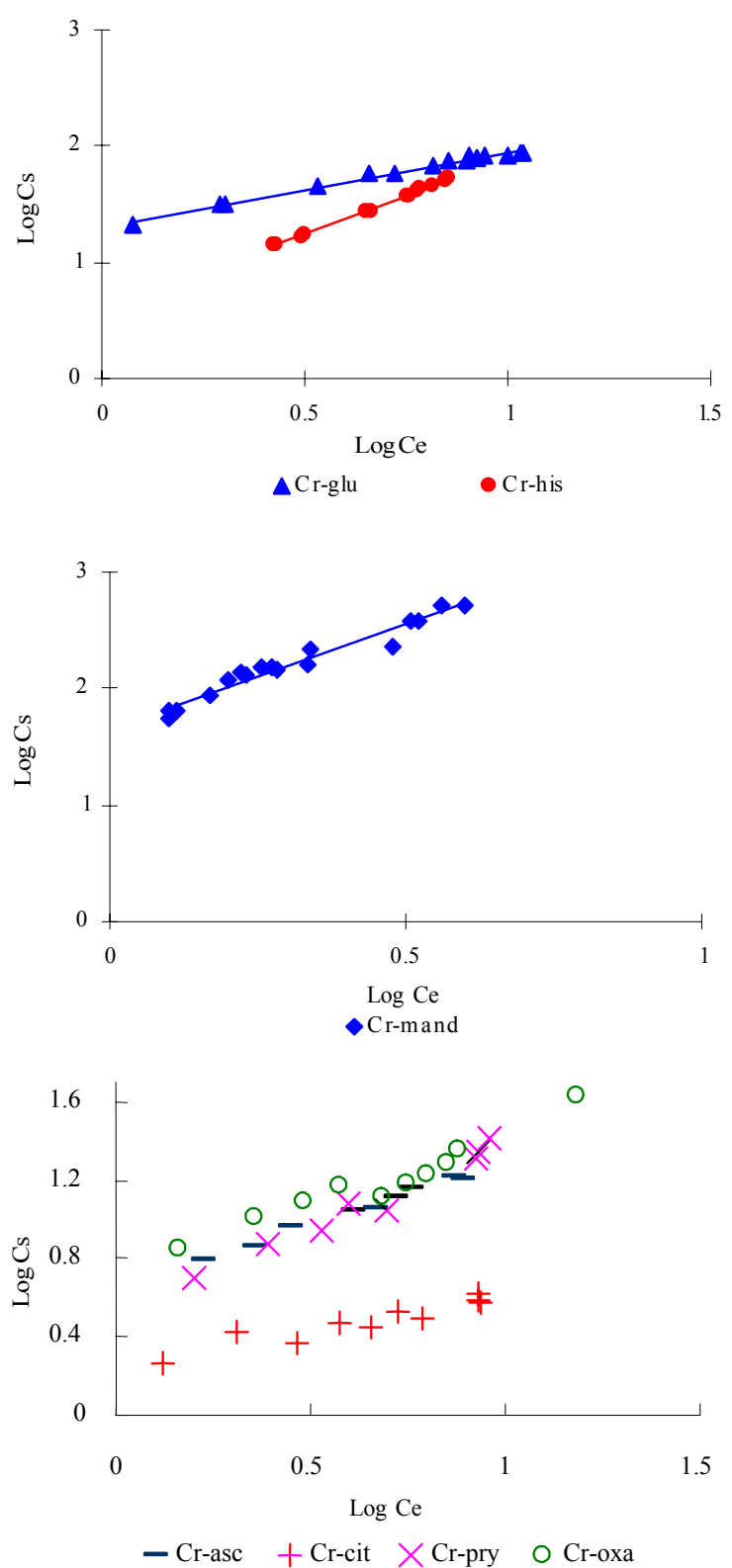

Fig. 5: Langmuir and Freundlich sorption isotherms for each $\mathrm{Cr}$ (III) organic complex at $30 \pm 2{ }^{\circ} \mathrm{C}, 0.01 \mathrm{M} \mathrm{KNO}_{3}, 5 \mathrm{mM} \mathrm{pH} 7$ buffer, $3 \mathrm{mM} \mathrm{NaN}_{3}$ and contact time of 10 days 

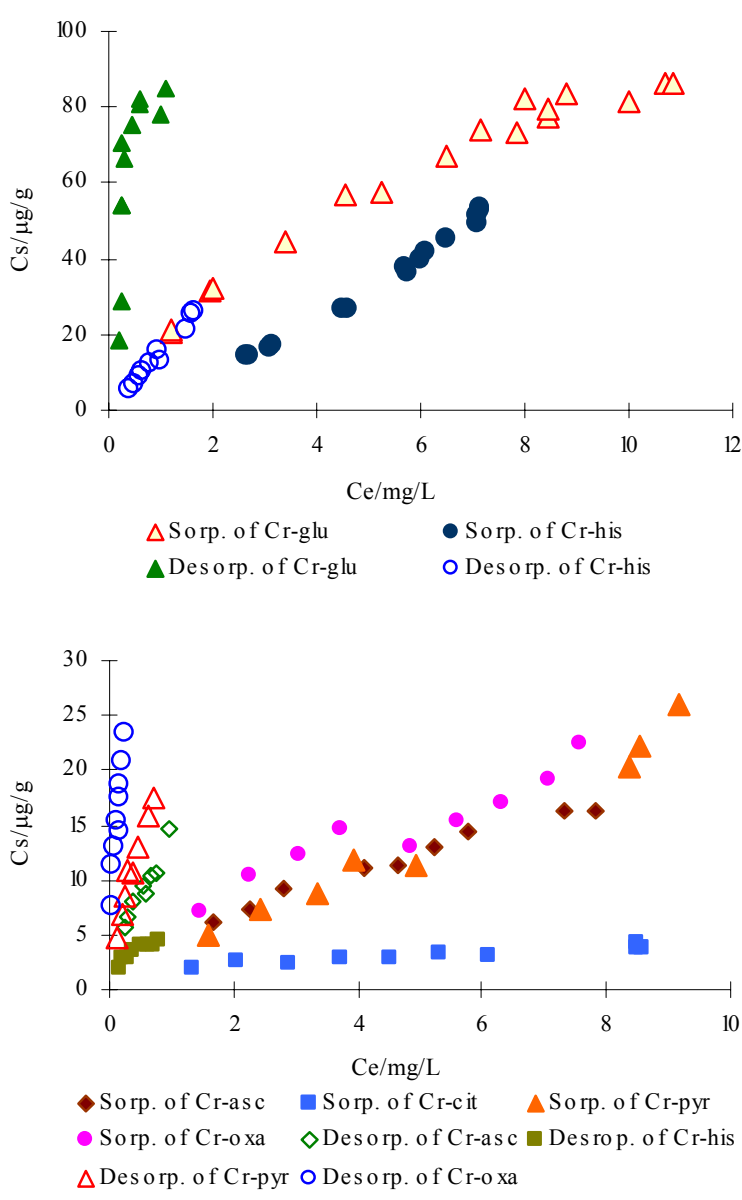

Fig. 6: Sorption and desorption data for selected $\mathrm{Cr}$ (III) organic complexes with the Matawan soil at $30 \pm 2{ }^{\circ} \mathrm{C}, 0.01 \mathrm{M}$ $\mathrm{KNO}_{3}, 5 \mathrm{mM}$ pH 7 buffer, $3 \mathrm{mM} \mathrm{NaN}$ and contact time of 10 days

observed, the desorption data could not be fitted to an isotherm model. Consequently, $\mathrm{Cr}$ (III) organic complexes remain sorbed to soil or sediment particles and would not exhibit high mobility.

Sorption and desorption of $\mathrm{Cr}$ (III) cys and $\mathrm{Cr}$ (III) serine with the Matawan soil was not reproducible; their data were not considered in this study. $\mathrm{Cr}$ (III) cys complexes have the $-\mathrm{SH}$ group which could be oxidized by $\mathrm{MnO}_{2}(\mathrm{~s})$ or other oxidants in this soil, changing the composition of this complex. The other plausible reason for the instability with both complexes is they exist as several species with different charges. The Cr (III) ser complex existed predominantly as a cationic species exhibiting complex sorption and desorption behavior. Additional research is needed to evaluate their sorption and desorption behavior.

\section{CONCLUSION}

At pHs of most natural environments ( $\mathrm{pH} 5$ to 9), a constant percent sorption was observed for each $\mathrm{Cr}$ (III) organic complex. Varying the ionic strength between 0.005 and $0.01 \mathrm{M} \mathrm{KNO}_{3}$ did not influence the sorption of each $\mathrm{Cr}$ (III) organic complex. The

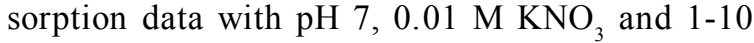
$\mathrm{mg} / \mathrm{L} \mathrm{Cr}$ (III) organic complex exhibited good fits with the Freundlich model. In addition, $\mathrm{Cr}$ (III) glut, $\mathrm{Cr}$ (III) pyr, $\mathrm{Cr}$ (III) oxa, $\mathrm{Cr}$ (III) cys, $\mathrm{Cr}$ (III) asc and $\mathrm{Cr}$ (III) cit could be fit with a Langmuir model. Estimates for the saturated sorption capacities were 141, 70.9, $36.5,35.5,28.6$ and $4.4 \mu \mathrm{g} / \mathrm{g}$, respectively. It was not possible to desorb significant amounts of the previously sorbed $\mathrm{Cr}$ (III) organic complexes. At the same $\mathrm{pH}$, ionic strength and solid:liquid ratio, the order of the observed sorption to the Matawan soil from highest to lowest is $\mathrm{Cr}$ (III) mand, $\mathrm{Cr}$ (III) glu, $\mathrm{Cr}$ (III) his, Cr (III) cys, Cr (III) ser, Cr (III) pyr, Cr (III) oxa, $\mathrm{Cr}$ (III) asc and $\mathrm{Cr}$ (III) cit. The highest percent of sorption is around $75 \%$ for the $\mathrm{Cr}$ (III) mand complex and the lowest percent of sorption is around $2 \%$ for the $\mathrm{Cr}$ (III) cit complex.

In fact, natural organic matters are more complicated than those ligands researched in this paper. The natural $\mathrm{Cr}$ (III) organic complexes are also complicated and varied. Although, those ligands are part of natural organic matters and have some similar function groups; this study can help to understand the behavior of sorption on soil particles. The mechanism and the possible transformation will be carried in the next study about natural organic $\mathrm{Cr}$ (III) complexes in soil.

\section{ACKNOWLEDGMENTS}

This research was supported partially by the Center for Contaminant Transport, Fate and Remediation at the Johns Hopkins University and in part by the China Scholarship Council (China), a program of the National Natural Science Foundation of China (40402020).

\section{REFERENCES}

Adams, T. K.; Saydam, N.; Steiner, F.; Schaffner, W.; Freedman, J. H., (2002). Activation of gene expression 
by metal-responsive signal transduction pathways. Environ. Health Perspect., 110 (5), 813-817 (5 pages). Ahern, F.; Eckert, J. M.; Payne, N. C.; Williams, K. C., (1985). Speciation of chromium in seawater. Anal. Chim. Acta., 175, 147-151 (5 pages).

Buerge-Weirich, D.; Behra, P.; Sigg, L., (2003). Adsorption of copper, nickel and cadmium on goethite in the presence of organic ligands. Aquat. Geochem., 9 (2), 65-85 (21 pages).

Carbonaro, R.; Stone, A. T., (2005). Speciation of chromium (III) and cobalt (III) (amino) carboxylate complexes using capillary electrophoresis. Anal. Chem., 77 (1), 155-164 (10 pages).

Clescerl, L. S.; Greenberg, A. E.; Eaton, A. D., (1989). Standard methods for examination of water and wastewater, $17^{\text {th. }}$ Ed., American Public Health Association.

Costa, M., (2003). Potential hazards of hexavalent chromate in our drinking water. Toxicol. Appl. Pharma., 188 (1), $1-5$ (6 pages).

Davis, A.; Kempton, J. H.; Nicholson, A.; Yare, B., (1994). Groundwater transport of arsenic and chromium at a historical tannery. Woburn, Massachusetts, U.S.A. Appl. Geochem., 9 (5), 569-582 (14 pages).

Freundlich, H., (1926). Colloid and capillary chemistry, Methuen. London, 397-414.

Fukushima, M.; Nakayasu, K.; Tanaka, S.; Nakamura, H. (1995). Chromium (III) binding abilities of humic acids. Anal. Chim. Acta., 317 (1-3), 195-206 (12 pages).

Gaspar, A.; Buglyo, P., (2000). Separation and kinetic study of chromium (III) chlorocomplexes by capillary electrophoresis. Chromatographia, 51 (1), 143-147 (5 pages).

Ge, Y.; Hendershot, W., (2004). Evaluation of soil surface charge using the back-titration technique. Soil Sci. Soc. Am. J., 68, 82-88 (7 pages).

Holdway, D. A., (1988) The toxicity of $\mathrm{Cr}$ to fish, in chromium in the natural and human environments. Nriagu, J. O.; Nieboer, E., Eds., John Wiley and Sons, Advances in Environmental Science and Technology No. 20; WileyInterscience: New York, 369-397.

Howe, J. A.; Loeppe R. H.; DeRose, V. J.; Hunter, D. B.; Bertsch, P. M., (2003). Localization and speciation of chromium in subterranean clover using XRF, XANES and EPR Spectroscopy. Environ. Sci. Tech., 37 (18), 4091 4097 (7 pages).

Huang, C.; Zhang, Q.; Li, J.; Shi, X.; Castranova, V.; Ju, G.; Costa, M.; Dong, Z., (2001). Involvement of Erks activation in cadmium-induced AP-1 transactivation in vitro and in vivo. Mol. Cell. Biochem., 222 (1-2), 141147 (7 pages).

Icopini, G. A.; Long, D. T., (2002). Speciation of aqueous chromium by use of solid-phase extractions in the field. Environ. Sci. Tech., 36 (13), 2994-2999 (5 pages).

Kaczynski, S. E.; Kieber, R. J., (1994). Hydrophobic $C_{18}$ bound organic complexes of chromium and their potential impact on the geochemistry of chromium in natural waters. Environ. Sci. Tech., 28 (5), 799-804 (5 pages).

Langmuir, I., (1918). The adsorption of gases on plane surface of glass, mica and platinum. J. Am. Chem. Soc., 40, 1361-1403 (42 pages).
Mattuck, R.; Nikolaidis, N. P., (1996). Chromium mobility in freshwater wetlands. J. Comtam. Hydrol., 23 (3), 213 232 (20 pages).

Nakayama, E.; Kuwamoto, T.; Tokoro, H.; Fujinaga, T., (1981). Dissolved state of chromium in seawater. Nature, 290, 768-770 (3 pages).

Nieboer, E.; Jusys, A. A., (1988). Biological chemistry of Cr, in chromium in the natural and human environments. Nriagu, J. O.; Nieboer, E., Eds., John Wiley and Sons, Advances in Environmental Science and Technology No. 20; Wiley-Interscience: New York, 21-79.

Ogundiran, O. O.; Afolabi, T. A., (2008). Assessment of the physicochemical parameters and heavy metals toxicity of leachates from municipal solid waste open dumpsite. Int. J. Environ. Sci. Tech., 5 (2), 243-250.

Oshida, P. S.; Word, L. S.; Mearns, A. J., (1981). Effects of hexavalent and trivalent $\mathrm{Cr}$ on the reproduction of Neanthes arenaceodentata (polychaeta). Mar. Environ. Res., 5, 41-49 (9 pages).

Pearson, R. G., (1963). Hard and soft acids and bases. J. Am. Chem. Soc., 85, 3533-3539 (6 pages).

Petruzzelli, G.; Guidi, G.; Lubrano, L., (1985). Ionic strength effect on heavy metal adsorption by soil. Commun. Soil Sci. Plan., 16 (9), 971-986 (16 pages).

Puzon, G. J.; Roberts, A. G.; Kramer, D. M.; Xun, L., (2005). Formation of soluble organo-Chromium (III) complexes after chromate reduction in the presence of cellular organics. Environ. Sci. Tech., 39 (8), 2811-2817 (7 pages).

Puzon, G. J.; Tokala, R. K.; Zhang, H.; Yonge, D.; Peyton, B. M; Xun, L., (2008). Mobility and recalcitrance of organo-chromium (III) complexes. Chemosphere, 70 (11), 2054-2059 (5 pages).

Richard, F. C.; Bourg, A. C. M., (1991). Aqueous geochemistry of chromium: A review. Water Res., 25 (7), 807-816 (10 pages).

Sass, B. M.; Rai, D., (1987). Solubility of amorphous chromium III-iron (III) hydroxide solid solutions. Inorg. Chem., 26 (14), 2228-2232 (5 pages).

Sivakumar, S.; Subbhuraam, C. V., (2005). Toxicity of chromium (III) and chromium (VI) to the earthworm Eisenia fetida. Ecotox. Environ. Safe., 62 (1), 93-98 (6 pages).

Shah, B. A.; Shah, A. V.; Singh, R. R., (2009). Sorption isotherms and kinetics of chromium uptake from wastewater using natural sorbent material. Int. J. Environ. Sci. Tech., 6 (1), 77-90 (14 pages).

Shrestha, R.; Fischer, R.; Sillanpaa, M., (2007). Investigations on different positions of electrodes and their effects on the distribution of $\mathrm{Cr}$ at the water sediment interface. Int. J. Environ. Sci. Tech., 4 (4), 413-420 (7 pages).

Stumm, W.; Morgan, J. J., (1996). Aquatic chemical equilibrium and rates in natural water. $3^{\text {rd. }}$ Ed., John Wiley and Sons, Inc., New York, Wiley-Interscience, 1022.

Vitale, R. J.; Mussoline, G. R.; Rinehimer, K. A., (1997). Environmental monitoring of chromium in air, soil and water. Regul. Toxicol. Pharm., 26 (1-2), 80-85 (6 pages). von Gunten, H. R.; Kull, T. P., (1986). Infiltration of inorganic compounds from the glatt river. Switzerland, 
into a groundwater aquifer. Water Air Soil Pollut., 29 (3), 333-346 (14 pages).

Walsh, A. R.; O'Halloran, J., (1996). Chromium speciation in tannery effluent-I, an assessment of techniques and the role of organic chromium (III) complexes. Water Res., 30 (10), 2393-2400 (8 pages)

Walsh, A. R.; O'Halloran, J., (1997). The accumulation of chromium by mussels Mytilus edulis (L.) as a function of valency, solubility and ligation. Mar. Environ. Res., 43 (1-2), 41-53 (13 pages).

Wang, W. X.; Griscom, S. B.; Fisher, N. S., (1997). Bioavailability of $\mathrm{Cr}$ (III) and $\mathrm{Cr}$ (VI) to marine mussels from solute and particulate pathways. Environ. Sci. Tech., 31 (2), 603-611 (9 pages).

\section{AUTHOR (S) BIOSKETCHES}

Luo, Z., Ph.D., Associate Professor, School of Environmental Studies, China University of Geosciences, China.

Visiting scholar in the Department of Geography and Environmental Engineering, G.W.C Whiting School of Engineering, The Johns Hopkins University, Baltimore, Maryland, USA. Email: zjluo@cug.edu.cn

Wadhawan, A., M.Sc., Ph.D. Candidate, Department of Geography and Environmental Engineering, G.W.C Whiting School of Engineering, The Johns Hopkins University, Baltimore, Maryland, USA. Email: awadhaw1@jhu.edu

Bouwer, E. J., Ph.D., Full Professor, Department of Geography and Environmental Engineering, G.W.C Whiting School of Engineering, The Johns Hopkins University, Baltimore, Maryland, USA. Email: bouwer@jhu.edu

How to cite this article: (Harvard style)

Luo, Z.; Wadhawan, A.; Bouwer, E. J., (2010). Sorption behavior of nine chromium (III) organic complexes in soil. Int. J. Environ. Sci. Tech., $7(1), 1-10$. 